\title{
The Sinews of Governance: Bureaucracy, Narrative, and Power under Colonialism and Independence
}

\author{
IMRAN ALI
}

This paper attempts to explore the production of an exegesis of written output by a civil bureaucracy, and to compare this output over two periods of governance. On the one part was the British bureaucracy in the Indus region, but more especially the Punjab, during British rule; and on the other the bureaucracy in Pakistan after 1947. The intention of the paper is to analyse the problematic of governance from a somewhat different approach, and one which to the author's knowledge has yet not been undertaken, in our efforts to understand the power dynamics that have moulded the contours of governance in the Indus region in modern times. I have attempted elsewhere an analysis of these processes and developments. ${ }^{1}$ Therefore, rather than revisit these materials and arguments, I will suggest here a complementary yet distinct perspective for probing into the complexities of power and governance in this region. The question to be posed is whether, and how, could the emergence of a descriptive and analytical written discourse, by public officials, itself become the articulation of a narrative of power, authority and control. Moreover, in comparing the two periods, we might be able to glean some insights into the capability needs of public management and local and national governance systems, in addressing the challenging political and socio-economic environment facing contemporary Pakistan. These are huge areas of analysis, and mostly uncharted ones. The present paper can only hope to raise some relevant questions, and suggest some pertinent, if tentative, answers.

With the depleted educational resources of the colonial environment, and arguably also of independent Pakistan, the bureaucracy represented a highly concentrated segment of the most educated, and presumably also of some of the most talented, people in society. The civil bureaucracy also played an instrumental role in the state's decision making process. This obtained especially under colonial rule, with its minimisation of native and participatory involvement in governance. Indeed, as I have discussed elsewhere, state officials gained considerably in authority in the hydraulic society of the Indus irrigation system, with its more centralised control over land distribution and the

\footnotetext{
Imran Ali<iali@lums.edu.pk> is Professor of Economic History and Business Policy, Lahore University of Management Sciences, Lahore, Pakistan.

${ }^{1}$ See, for example, Imran Ali: "Malign Growth? Agricultural Colonisation and the Roots of Backwardness in the Punjab", Past and Present (Oxford), February 1987; "The Punjab and the Retardation of Nationalism". In D.A. Low (ed.) The Political Inheritance of Pakistan (London, Macmillan, 1991); "The Historical Lineages of Poverty and Exclusion in Pakistan", South Asia, Vol. XXV, No.2, August 2002; "Historical Impacts on Political Economy in Pakistan". Asian Journal of Management Cases, Vol. 1, No. 2 (2004).
} 
water source. ${ }^{2}$ But this equation held almost equally under Pakistan's own authoritarian and non-democratic political environment, which tended to concentrate decision making within a more restricted circle. This region continued to suffer the dearth, for research output, of deep and better quality human resources in higher education. This situation continued significantly into the post-colonial period. The role of the civil bureaucracy thus became even more pivotal, both as a repository of knowledge on society and governance within its own ranks, and as a conveyor of that knowledge to an external audience. It is therefore relevant to enquire into the quality and extent of the knowledge creation that this institution has contributed for governance in this region.

In trying to identify problems of governance in contemporary Pakistan, the importance of the analytical and information collection, processing and dissemination role of the bureaucracy cannot be overstated. It is for one an indicator of the level of quality of the bureaucracy; and the question can be posed in which direction this moved in the first and second halves of the twentieth century, lying on either side of the break from imperialist rule. If there are quality differentials in the two periods, then what reasons could be ascribed to them. Such an enquiry would also reflect the ability to conduct an effective public management role. The more superior the knowledge base developed within an institution, and the more efficiently that it is conveyed through that institution and beyond, the greater presumably would be its capacity to maintain both an appropriate strategic positioning, as well as the capacity for more effective micro-management. It could be argued that the civil bureaucracy's role as a fulcrum of authority for the projection of state power can be correlated with the degree to which it has over time produced the kinds of analyses and understanding of political and socio-economic trends and forces that might justify, though not necessarily legitimise, its exercise of such influence.

Through a robust exercise of these intellectual capabilities, the bureaucracy could achieve a greater indispensability. It could thereby become a core resource for the 'software' that must now accompany successful societal management. Conversely, a failure to fulfil such a role, or a level of performance that compares adversely with other periods or other environments, can create vulnerability for the bureaucracy. Its performance can be judged a relapse from the level of commitment and inputs required of such an institution in the contemporary world, where a more skilful and sophisticated quality of decision making and policy implementation is expected. This malaise can also be reflected in weakness or failure to generate stimuli for reform and revitalisation, both of internal structures and processes, and of external institutions. The bureaucracy can then begin to get marginalised, with other intermediaries and stakeholders appearing as custodians of the public domain. Therefore, the absence of the exegesis of analytical output and information flows, as a measure of quality, can expose it to highly detrimental impacts. These can extend to questioning the very rationale for the bureaucracy in its existing organisational framework, and to efforts to alter that framework to meet the needs of modernisation. The silence of the bureaucracy for societal analysis and for projecting its vision, mission and world view, can itself be taken as a measure of its incapacity and under-performance. This could advance and embolden external threats, in the face of a perceived internal failure for transformational capabilities.

${ }^{2}$ See Imran Ali, The Punjab under Imperialism, 1885-1947 (Princeton University Press, 1988; and Oxford University Press: Delhi, 1989, and Karachi, 2003). 
A word on what is denoted by the term 'bureaucracy'. In the wider sense, the term includes all personnel of the civil administration. More specifically, in the colonial administration the upper echelon representing this term was the central Indian Civil Service, or ICS. This was composed in all senior grades of ethnic British officers, though progressively in the twentieth century native Indian personnel were inducted at the more junior levels. The provincial administration was manned more heavily by native officials, whose cadre functioned from the patwari to tahsildar level and to secretariat roles. The ICS baseline was district level administrative, judicial and revenue collecting functions, which then extended to the divisional and provincial administration, and then to the secretariat departments of the Government of India. At times British military officials also switched, usually in early career, to the civil service. One example was Captain Popham Young, the Colonisation Officer of the Lower Chenab Colony in Punjab, who managed land settlement operations in the largest agricultural colonisation project in British India.

It is this segment, the 'elite' civil service, on which this paper will primarily focus for the British period, and on its post-1947 successor, the Civil Service of Pakistan, or CSP. The latter was formally destructured in the 1970s under the public administration reforms of the Peoples Party government of Zulfiqar Ali Bhutto. The old formation did not exactly disappear, but was bifurcated into a secretariat group and a district management group (or DMG). Despite this seeming setback, the civil service returned with increased authority under the military regime of Zia-ul-Haq, in the absence of countervailing democratic institutions. The local government reforms of the Musharraf regime attempted to realign the local moorings of this institution, by abolishing the divisional administration and replacing the Deputy Commissioner with the District Coordination Officer, or DCO, now reporting to the district mayors, or zilla nazims. However, the DCO's, at least in the early stages of local government reform, were inducted from the DMG cadre. They have tended to remain within the bureaucratic chain of command, rather that align their loyalties to a still fledgling local governance structure.

One of the most evident contrasts between the intellectual performance of the preand post-1947 civil bureaucracies lies in the compilation of district gazetteers. These gazetteers covered physical, economic, social, ethnographic and cultural aspects of each district. They were not only a ready source of reference for information on a district, but in their own way could be regarded as masterpieces of descriptive analysis. They also represent a narrative of power, in that the pre-1947 gazetteers were compiled by an alien, hegemonic force, which clearly identified in the gathering and processing of local knowledge a means of exercising control. For all the worthwhile and intrinsically important information that they contain, the district gazetteers, like much else of the colonial intellectual exegesis, are also documents of power; and part of a master narrative of imperialist hegemony. Nevertheless, the sheer fact that they were produced, and apparently for each district of every province of British India, was itself a notable achievement. Equally remarkable was the fact that for the Punjab, during the century of British control, no less than three sets of gazetteers were compiled for each district of the province: in the 1880s, 1910s and 1930s. Clearly, in making this sizeable effort, the British must have felt that the updating of information on local conditions was important for local governance, as well as a useful tool for top management decision making. The 
outcome was a corpus of literature that went well beyond the realm of administrative needs, and became a valuable form of documentation on local conditions.

It is an equally remarkable fact that since 1947 , a period of six decades, the civil administration in Pakistan has not been able to produce even a single gazetteer of a single district. This is an onerous gap, especially when compared to the output of the colonial administration, with much more primitive resources for data collection and retrieval. Further, this vacuum has not been from lack of effort. In the 1980s financial resources were devoted to producing some district gazetteers, but apparently not even a single one was successfully completed. There is now no ready source of reference for local knowledge, within a single and identifiable set of volumes or documents. The implications for local government functioning can be readily surmised. The reasons for this lapse on the part of the Pakistani bureaucracy can range from intellectual apathy to lack of capability, or they could be lack of time or application, or absorption with petty operations or petty politicking.

Yet the need is very much present. As local governments are established and try to seek sustainability, they will need such documentation, statistical data and analysis for a number of functions, like approaching donors for social sector and infrastructure assistance, promoting trade and industry, reviving the local economy and highlighting any comparative and competitive advantages, seeking domestic and foreign investment, enhancing local incomes through tourism promotion. There can be major returns in maintaining a database of relevant indicators, to be able to understand trends and the direction in which ground realities are moving, and how rapidly these changes are occurring. Yet there are no signs that such a knowledge 'infrastructure' is being developed in a concerted manner. Governance does not come easily or automatically: a lot of hard effort is required for it to be effective. The alternative is anarchy, to which the term 'governance' can also be, and often is, attributed.

Another egregious shortfall lies in the area of access. Even the old gazetteers have become largely unobtainable. There are no libraries or public archives in which these materials are available: even the metropolitan centres are remiss in this resource. Some effort has been made by private publishers to print individual volumes. By contrast, for over 30 years the entire set of gazetteers, not only for Punjab but for every province of British India, have been available on microfiche, produced by a documentation reprographics company in Switzerland. I accessed these when I commenced my doctoral work at the Australian National University in Canberra. Two other examples reveal the adversity and disfunctionality in access to historical data in Pakistan. In Canberra, I was able to study the transcripted and printed debates and proceedings of the Punjab Legislative Council, from its inception in 1897, and of the later Punjab Legislative Assembly. One would be hard put to locate these anywhere in Pakistan itself. It is uncertain whether such care has been taken to accurately reproduce and archive the proceedings of the modern national and provincial legislatures, at least in terms of access for research.

The second example was in my search for statistics on demographic changes in Punjab districts from the $1880 \mathrm{~s}$, as a consequence of the opening of a new agrarian frontier based on canal irrigation in western Punjab, and the sizeable introduction of land grantees and labouring groups, especially from central Punjab. Teaching at the University 
of Melbourne at the time, I was highly relieved to find in the University library the full set of Indian (and Punjab) census reports, from 1881 to 1941. Again, ready access to such documents in any library would be highly problematical in Pakistan, though private publishers have printed the narrative section of perhaps the most well known and important volume of this set: Denzil Ibbetson's classical statement on the Punjab castes in the 1881 census report. ${ }^{3}$ Taking this treatise itself, there has not been even a remotely comparable effort at ethnographic analysis by any member of the Pakistani bureaucracy over the past sixty years.

The district gazetteers and other printed documents were only the tip of the iceberg of the colonial administration's analysis of local economy and society. Before we turn to books and longer treatises published by British officials, it might be useful to identify the information flows passing through the bureaucracy. This information kept the higher officials aware of ground realities, while their concerns, perceptions, advice and instructions could in turn be conveyed to their junior colleagues. There was on the one hand a voluminous correspondence that was sent along the hierarchy, both upwards and downwards, for decision making in the various provincial departments, and with the Government of India when it came under central purview. The two most significant provincial departments were Home and Revenue, while the most important parts of such correspondence and executive decisions were categorised as 'A' Files. They were printed and kept in the provincial record offices, and were sent on to London to the office of the Secretary of State for India, which was responsible for overseeing the British Indian empire. Coming from each province, and being filed as separate departmental proceedings, this material now forms the vast official holdings of the India Office Records and Library. These records were formerly located in London first at India House in Aldwych, then in Waterloo, and now comprise part of the new British Library in Kings Cross.

For numerous scholars, the India Office Records provided the base archival resource for research in South Asian studies, especially during the colonial period. While commencing my own doctoral research, I spent six months in London going through the Punjab Revenue Proceedings and other records for my $\mathrm{PhD}$ thesis on the Punjab Canal Colonies. ${ }^{4}$ The large amount of material that I was able to cover in this period was a testimony to the rapid access, even to obscure records, that was possible at the India Office. Even as an undergraduate at Sussex University, where the traditional sit down examination system had been replaced by assessment through dissertations, I became a somewhat precocious user of the India Office Records for research on my two major dissertations, on Punjab politics in the decade before Partition, and on the development of the Lower Chenab Colony. ${ }^{5}$

As opposed to the highly efficient retrieval system of the India Office in London, the provincial archives in Lahore, housed in the Anarkali tomb building in the Secretariat, is highly inefficient, and has virtually collapsed over time. The obstructive approach of

${ }^{3}$ See D.C.J. Ibbetson, Punjab Castes (reprint, Patiala, 1970).

${ }^{4}$ See Imran Ali, The Punjab Canal Colonies, 1885-1940 (Australian National University PhD thesis, 1980).

5"The Inception of a Society: The Chenab Canal Colony in the Punjab", and "Relations between the Muslim League and the Unionist Party: A Study in Punjab Politics in the Decade before Partition" (1973, Honours dissertations, University of Sussex). 
the staff, and their inability to locate material, has achieved the purpose of deterring research on the Punjab at its home base. This has not only killed off research by local scholars, but has suffocated the flow of foreign scholars, and thereby deflected the opportunity of their developing empathy with Pakistan. The civil bureaucracy, as the guardian of these records, stands squarely to blame for this neglect and deprivation of access. Questionably, if the colonial bureaucracy saw its route to better governance through fact gathering and analysis, then what were the goals of the Pakistani bureaucracy in rejecting research and the production of knowledge? This might not have been done deliberately, but callous institutional neglect has achieved exactly that outcome.

Even deeper reams of 'governance literature' are embedded within the provincial revenue proceedings or as a separate catalogue item in the India Office, and the lucky survivors could be accessed in the Board of Revenue Library in the Punjab Secretariat, Lahore. These were the tahsil level assessment reports and the district level settlement reports. These were produced to decide upon the reassessment of land revenue, for periods varying from 10 to 30 years for different districts. Land revenue was the most important source of income for the colonial state; and it also provided the fiscal basis for the record of rights that established proprietorship over agricultural land. Since recruitment into the military, especially in the vital Punjab province, was virtually confined to the landowning castes, the triangular relationship between land revenue, property rights and military-social status cemented the bonds between imperialism and the landlord and upper peasant stratum. It was important for the colonial state that revenue assessments be consistent with its own fiscal needs, reflect changed conditions and agrarian production capacity, and yet not be unduly unfair on agriculturists.

Needless to say, this highly significant means of acquiring local information and insights was not maintained by the post-1947 bureaucracy. The entire process of production of copious reports for revenue resettlements has lapsed completely. One reason has been that land revenue itself has been eclipsed as a significant source of state revenue. Its real value has diminished considerably through the retention of anachronistic rates, and the removal of small holders from the malikana net from the 1970s.

In the process of discarding revenue resettlement work, what Pakistani public servants completely lost out on was, to my mind, the core methodology through which the British officials developed their expertise on local society and governance. This was the work of development of a district's revenue settlement report, a process that could take up to five years. The young British inductee, no more than in his mid-twenties, would be posted as the settlement officer. He would be guided by another classic of official literature, J.M. Douie's Punjab Land Settlement Manual, which is now virtually unknown to Pakistani officials, though I have heard one recently retired Chief Secretary refer to this personage as "McDouie". The settlement officer, probably educated on classics, history and literature, and luckily bereft of the modern 'social sciences' then did his ' $\mathrm{PhD}$ ' on the realities of the district's economy and power structure. He first examined a large number of village records, to ascertain the mauza's production levels and hence revenue paying capacity. From these investigations he compiled in turn a copious Assessment Report for each tahsil of the district. Each report would be sent for comments and review to the divisional Commissioner, the Finance Commissioner and 
then the Governor. By this means the upper official hierarchy was constantly getting information on local conditions from different parts of the province. The final stage was the compilation of the district Settlement Report, which was really the summation of the assessment reports and established fixed revenue rates till the next settlement. In the canal colony districts fluctuating rates were adopted owing to rapidly evolving conditions. ${ }^{6}$

By the completion of this process of completing the revenue resettlement of a district, the British civil officer was ready to take on the burden of empire. His training was arguably far more comprehensive than the modern alternative of sending officials for largely irrelevant American Masters degrees, and now to vacuous short courses at Harvard University's exorbitant School of Government. It should be noted that in the latter years of British rule, native officials were also entrusted with revenue resettlement work. The Assessment Reports and Settlement Report for Jhang District in the 1920s were produced by Mian Abdul Aziz, and those for Gujrat District by Ahmed Hassan Khan. They in no way are lesser in quality than those produced by British officials. Also, the Colonisation Officers in the earlier canal colonies were British. Popham Young's Settlement Report of the Lower Chenab Colony (1915) is another impressive treatise. The Colonisation Officer of the Lower Jhelum Colony was the legendary Malcolm Hailey, who later rose to be Governor first of Punjab and then the United Provinces, and after retirement wrote The African Survey, which is still regarded as a classic in African studies. By the time of the Nili Bar Colony in the late 1920s, the Colonisation Officer was Mr. G. Mueenuddin.

Finally, one can conclude by mentioning some larger works that stand out for their erudition, empirical validity or authentic analysis. Some of these are S.S. Thorburn, Mussalmans and Moneylender in the Punjab (1886) and The Punjab in Peace and War (1904); J.M. Wikely, Punjabi Mussalmans (1915); H.K. Trevaskis, The Land of the Five Rivers (1928) and The Punjab of Today (1931); H.A. Rose, A Glossary of the Tribes and Castes of the Punjab and North-West Frontier Province (1914); H.C. Calvert, The Wealth and Welfare of the Punjab (1936); and of course M.L. Darling, Rusticus Loquitor or the Old Light and the New in the Punjab Village (1930), Wisdom and Waste in the Punjab Village (1934), and The Punjab Peasant in Prosperity and Debt ( $4^{\text {th }}$ ed., 1947). Not to be overlooked is L.H. Griffin and C.F. Massy, Chiefs and Families of Note in the Punjab (1940), which has provided many individuals with information on their own personal histories.

To end, I have before me an extremely well written and exquisitely produced book titled The Land of the Five Rivers and Sindh (1883) by David Ross. It has my grandfather's signature on it, the words 'Aitchison College, Lahore', and a date of 1888. Having joined in 1886 with the first class at Aitchison, he was hardly in his teens when he used this book, which would compare favourably with most texts being used today. Clearly, this education did have an impact, since he looked beyond the feudal mode and lived increasingly in Lahore, New Delhi and Simla, the summer capital of the Government of India and the Punjab Government. He even wrote three books that reflected his mind set: on Ranjit Singh, the ruler of independent Punjab; on his favourite

${ }^{6}$ See a list of several Assessment Reports and Settlement Reports in the bibliography of given in: The Punjab under Imperialism, 1885-1947 by Imran Ali. 
personage in history as the last Pathan ruler of India, Sher Shah Suri; and one of the first books in English on his close friend, Muhammad Iqbal, titled A Voice from the East. ${ }^{7}$ Interestingly, the translation into English of Iqbal's Persian poetry for this book was done by another extremely close friend, Sir Umrao Singh Majithia. 